$\begin{array}{ll}\text { Pedlagfogika } & \begin{array}{l}\text { Pedagogika: Jurnal Pedagogik dan Dinamika Pendidikan } \\ \text { P-ISSN2252-6676 E-ISSN2746-184X, Volume.9, No.1, April2021 } \\ \text { doi: https://doi.org/10.30598/pedagogikavol9issue1year2021 }\end{array} \\ \text { https://ojs3.unpatti.ac.id/index.php/pedagodika, } \\ \text { email: jurnalpedagogika@gmail.com }\end{array}$

\title{
STRATEGI SEKOLAH DALAM PENGUATAN PENDIDIKAN KARAKTER MELALUI KEMITRAÄN DENGAN KELUARGA SENDIRI PADA SD NEGERI 2 HULALIU
}

\author{
Nathalia Yohanna Johannes ${ }^{1}$, Lisye Salamor ${ }^{2}$, Eukaristy Stevania Taihuttu ${ }^{3}$ \\ Program Studi PGSD FKIP Universitas Pattimura Ambon ${ }^{1,3}$ \\ Program Studi Pkn FKIP Universitas Pattimura Ambon ${ }^{2}$ \\ email: nathaliayjohannes@gmail.com
}

Abstrak, Penelitian ini bertujuan untuk melakukan kajian tentang strategi sekolah dalam penguatan pendidikan karakter bagi siswa SD Negeri 2 Hulaliu dengan memaksimalkan peran orang tua. Metode peneltian yang digunakan adalah kualitati deskriptif. Dari hasil penelitian terlihat bahwa penerapan strategi sekolah dalam penguatan pendidikan karakter di SD Negeri 2 Hulaliu, sekolah memberikan ruang bagi orang tua murid agar dapat membangun hubungan yang baik antara guru dan siswa dan siswa dengan temannya.

Keywords: Strategi, Pendidikan Karakter, Kemitraan, Keluarga

\author{
SCHOOL STRATEGIES IN STRENGTHENING CHARACTER EDUCATION FOR \\ STUDENTS BY MAXIMIZING THE ROLE OF PARENTS AT SD NEGERI 2 HULALIU \\ Nathalia Yohanna Johannes ${ }^{1}$, Lisye Salamor ${ }^{2}$, Eukaristy Stevania Taihuttu ${ }^{3}$ \\ Program Studi PGSD FKIP Universitas Pattimura Ambon ${ }^{1,3}$ \\ Program Studi Pkn FKIP Universitas Pattimura Ambon ${ }^{2}$ \\ email: nathaliayjohannes@gmail.com
}

\begin{abstract}
This study aims to conduct a study of school strategies in strengthening character education for students of SD Negeri 2 Hulaliu by maximizing the role of parents. The research method used is descriptive qualitative. From the results of the study, it can be seen that the implementation of school strategies in strengthening character education in SD Negeri 2 Hulaliu, the school provides space for parents of students to be able to build good relationships between teachers and students and students with their friends.
\end{abstract}

Keywords: The role of family, government, discipline, children's learning hours 


\section{PENDAHULUAN}

Penyelenggaraan pendidikan karakter menjadi satu hal yang multlak dilakukan di jenjang pendidikan manapun. Hal ini sangat beralasan karena pendidikan adalah pondasi utama bagi tumbuh kembang generasi muda Indonesia. Pendidikan karakter merupakan suatu sistem penerapan nilai-nilai moral pada peserta didik melalui ilmu pengetahuan, kesadaran atau kemauan, dan implementasi nilai-nilai tersebut, baik terhadap diri sendiri, sesama, lingkungan, bangsa dan negara maupun Tuhan Yang Maha Esa, kebangsaan sehingga menjadi manusia yang memiliki akhlaqulkarimah (Dalimunthe, 2015). Pendidikan karakter merupakan gerakan nasional untuk menciptakan sekolah yang membina generasi muda yang beretika, bertanggung jawab, dan peduli. Pendidikan karakter juga bukan hanya sekedar mengajarkan mana yang benar dan mana yang salah. Lebih dari itu, pendidikan karakter adalah usaha menanamkan kebiasaan-kebiasaan yang baik (habituation) sehingga siswa mampu bersikap dan bertindak berdasarkan nilai-nilai yang telah menjadi kepribadiannya. Johannes, Ritiauw dan Abidin (2020), mengemukakan bahwa bahwa tujuan dari pendidikan karakter adalah untuk membentuk dan mengembangkan potensi siswa agar berperilaku baik sesuai dengan falsafah Pancasila, dapat berpartisipasi di lingkungan masyarakat dan bertanggung jawab sebagai warga Negara yang baik. Dengan kata lain, pendidikan karakter yang baik harus melibatkan pengetahuan yang baik (moralknowing), perasaan yang baik atau lovinggood (moral feeling) dan perilaku yang baik (moral action) (Safitri, 2015).

Peraturan Presiden No. 87 tahun 2017 tentang Penguatan Pendidikan Karakter hadir dengan pertimbangan bahwa dalam rangka mewujudkan bangsa yang berbudaya melalui penguatan nilai-nilai religius, jujur, toleran, disiplin, bekerja keras, kreatif, mandiri, demokratis, rasa ingin tahu, semangat kebangsaan, cinta tanah air, menghargai prestasi, komunikatf, cinta damai, gemar membaca, peduli lingkungan, peduli sosial dan bertanggung jawab, pemerintah memandang perlu pendidikan karakter. Pendidikan karakter merupakan penciptaan lingkungan sekolah yang membantu siswa dalam perkembangan etika, tanggung jawab melalui model, dan pengajaran karakter yang baik melalui nilai-nilai universal (Berkowitz \& Bier dalam Wulandari dan Kristiawan, 2017) Nilai-nilai karakter ini sudah seharusnya ditanamkan kepada siswa sehingga mereka mampu menerapkan dalam kehidupannya baik dikeluarga, sekolah, masyarakat, dan negara sehingga dapat memberikan kontribusi yang positif kepada lingkungannya.

Pendidikan karakter mempunyai tujuan penanaman nilai dalam diri siswa dan pembaruan tata kehidupan bersama yang lebih menghargai kebebasan individu. Selain itu, pendidikan karakter bertujuan meningkatkan mutu penyelenggaraan dan hasil pendidikan di sekolah yang mengarah pada pencapaian pembentukan karakter dan akhlak mulia siswa secara utuh, terpadu, dan seimbang sesuai dengan standard kompetensi lulusan. (Samani dan Hariyanto, 2011: 42-43).

Tujuan pendidikan karakter yang diharapkan Kementerian Pendidikan Nasional (sekarang: Kementerian Pendidikan dan Kebudayaan) adalah seperti berikut. Pertama, mengembangkan potensi kalbu/nurani/afektif siswa sebagai manusia dan warga negara yang memiliki nilai-nilai budaya dan karakter bangsa. Kedua, mengembangkan kebiasaan dan perilaku siswa yang terpuji dan sejalan dengan nilai-nilai universal dan tradisi budaya bangsa yang religius. Ketiga, menanamkan jiwa kepemimpinan dan tanggung jawab siswa sebagai generasi penerus bangsa. Keempat, mengembangkan kemampuan siswa menjadi manusia yang mandiri, kreatif, berwawasan kebangsaan. Kelima, mengembangkan lingkungan kehidupan sekolah sebagai lingkungan belajar yang aman, jujur, penuh kreativitas dan persahabatan, serta dengan rasa kebangsaan yang tinggi dan penuh kekuatan (dignity) (Kemdiknas, 2010: 9).

Ada tiga fungsi utama pendidikan karakter. Pertama, fungsi pembentukan dan 
pengembangan potensi. Pendidikan karakter membentuk dan mengembangkan potensi siswa agar berpikiran baik, berhati baik, dan berperilaku sesuai dengan falsafah pancasila. Kedua, fungsi perbaikan dan penguatan. Pendidikan karakter memperbaiki dan memperkuat peran keluarga, satuan pendidikan, masyarakat, dan pemerintah untuk ikut berpartisipasi dan bertanggung jawab dalam pengembangan potensi warga negara dan pembangunan bangsa menuju bangsa yang maju, mandiri, dan sejahtera. Ketiga, fungsi penyaring. Pendidikan karakter memilah budaya bangsa sendiri dan menyaring budaya bangsa lain yang tidak sesuai dengan nilai-nilai budaya bangsa dan karakter bangsa yang bermartabat. (Zubaidi, 2011:18)

Karakter berasal dari nilai tentang sesuatu. Suatu karakter akan melekat dengan nilai dari perilaku seseorang. Karena itu, dalam perspektif pendidikan karakter, tidak ada perilaku anak yang tidak bebas dari nilai (Kesuma, dkk., 2011:2). Nilai-nilai pendidikan karakter yang dikembangkan Kementerian Pendidikan dan Kebudayaan ada delapan belas karakter. Nilai-nilai tersebut bersumber dari agama, Pancasila, budaya, dan tujuan pendidikan nasional. Adapun delapan belas nilai tersebut yaitu:religius, jujur, toleransi, disiplin, kerja keras, kreatif, mandiri, demokratis, rasa ingintahu, semangat kebangsaan, cinta tanah air, menghargai prestasi, bersahabat/komunikatif, cinta damai, gemar membaca, pedulilingkungan, peduli sosial, dan tanggungjawab.Dilihat dari segi komponennya, pendidikan karakter lebih menekankan pentingnya tiga komponen karakter yang baik (components of good character) yaitu moralknowing atau pengetahuan tentang moral, moral feeling atau perasaan tentang moral dan moral action atau perbuatan bermoral. (Lickona, 1991:21)

Pemahaman yang mendalam dari praktisi pendidikan terhadap konsep pendidikan karakter menjadi taruhan bagi keberhasilan pendidikan karakter di setiap satuan pendidikan. Proses pendidikan karakter tidak dapat langsung dilihat hasilnya dalam proses waktu yang singkat, tetapi memerlukan proses yang kontinyu dan konsisten. Pendidikan karakter berkaitan dengan waktu yang panjang sehingga tidak dapat dilakukan dengan satu kegiatan saja. Itulah sebabnya pendidikan karakter sangat penting. Apa lagi bila kita melihat bergesernya nilai-nilai, moral dan prilaku generasi muda saat ini yang menjadi isu penting dalam dunia pendidikan Nasional saat ini, dimana pada periode ini, anak tengah mencari dan membangun identitas diri (Miller, 2011; Santrock, 2011). Data UNICEF tahun 2003-2013 menunjukkan bahwa perilakuperilaku kekerasan seperti bullying dan physical fightand attacks yang dilakukan oleh remaja usia13-15 tahun di Indonesia lebih tinggi dibanding di Malaysia, Vietnam, dan Thailand (UNICEF, 2014).

Hal tersebut memperlihatkan perlunya tindakan untuk membantu anak memiliki karakter yang kuat. Berdasarkan teori sistem ekologi, perkembangan individu tidak dapat dilepaskan dari lingkungan tempat individu tersebut berada (Darling, 2007; Glassman dan Hadad, 2009). Sandarwati (2016) mengemukakan bahwa lingkungan pertama yang sangat berpengaruh terhadap perkembangan kepribadian siswa adalah lingkungan keluarga. Lingkungan keluarga adalah lingkungan yang dialami anak dalam berinteraksi dengan anggota keluarga, baik interaksi secara langsung maupun tidak langsung. Suasana keluarga akan berpengaruh bagi perkembangan kepribadian anak. Siswa yang belajar akan menerima pengaruh dari keluarga berupa cara orang tua mendidik, relasi antar anggota keluarga, suasana rumah dan keadaan ekonomi keluarga. Ryan dan Lickona, (1992).

Oleh karena itu, sekolah harus dapat memanfaatkan peran orang tua yang sangat sentral dalam membina karakter siswa. Sekolah harus mampu menciptakan kolaborasi yang baik dengan keluarga dalam hal ini adalah oran gtua dalam membina karakter siswa. Untuk memaksimalkan peran orang tua sebagai upaya penguatan pendidikan karakter bagi siswa dibutuhkan strategi yang dapat memaksimalkan peran orang tua 
dalam upaya penguatan pendidikan karakter bagi siswa. Menurut Kotler (dalam Soesilo, 2002), strategi merupakan sekumpulan cara-cara untuk mencapai tujuan, sehingga strategi menjadi suatu pendekatan logis yang akan menentukan arah aksi. Sementara itu menurut Quin (dalam Soesilo (2002), strategi didefenisikan sebagai incremental approach, yaitu pola atau rencana yang mengintegrasikan tujuan utama, kebijakan dan urutan-urutan tindakan organisasi menjadi satu dalam keseluruhan yang kohesif. Dengan berlandaskan pada teori ini, dalam upaya penguatan pendidikan karakter sekolah harus memiliki strategi yang terintegrasi dengan baik dari segenap pihak terkait termasuk orang tua siswa agar tujuan pendidikan karakter dapat tercapai sebagaimana yang diharapkan oleh sekolah.

SD Negeri 2 Hulaliu Kecamatan Pulau Haruku Kabupaten Maluku Tengah menyadari bahwa pendidikan karakter merupakan upaya yang melibatkan semua pihak baik keluarga sebagai dasar, lingkungan sekolah serta masyarakat secara luas. Pembentukan dan pendidikan karakter tidak akan berhasil selama antar lingkungan pendidikan tersebut tidak ada kesinambungan dan keharmonisan. Selama ini, pendidikan informal di dalam keluarga cukup memberikan kontribusi berarti dalam mendukung pencapaian kompetensi dan pembentukan karakter peserta didik di SD Negeri 2 Hulaliu. Salah satu alternatif untuk menghindari permasalahan buruknya karakter anak, adalah melalui pendidikan karakter terpadu, yaitu memadukan dan mengoptimalkan kegiatan pendidikan informal yang ada dalam lingkungan keluarga dengan pendidikan formal di sekolah.

\section{METODOLOGI}

Penelitian ini menggunakan metode penelitian deskriptif kualitatif. Djam'an Satori (2011: 23) mengungkapkan bahwa penelitian kualitatif dilakukan karena peneliti ingin mengeksplor fenomena-fenomena yang tidak dapat dikuantifikasikan yang bersifat deskriptif seperti proses suatu langkah kerja, formula suatu resep, pengertian-pengertian tentang suatu konsep yang beragam, karakteristik suatu barang dan jasa, gambargambar, gaya-gaya, tata cara suatu budaya, model fisik suatu artifak dan lain sebagainya. Menurut Sugiono (2012: 9) penelitian kualitatif adalah metode penelitian yang berlandaskan pada filsafat postpositivisme, digunakan untuk meneliti pada kondisi objek alamiah, dimana peneliti adalah sebagai instrumen kunci, teknik pengumpulan data dengan triangulasi, analisis data bersifat induktif atau kualitatif, dan hasil penelitian kualitatif lebih menekankan makna daripada generalisasi.

Sementara Nana Syaodih Sukmadinata (2011: 73), menguraikan bahwa penelitian deskriptif kualitatif ditujukan untuk mendeskripsikan dan menggambarkan fenomena-fenomena yang ada, baik bersifat alamiah maupun rekayasa manusia, yang lebih memperhatikan mengenai karakteristik, kualitas, keterkaitan antar kegiatan. Penelitian deskriptif tidak memberikan perlakuan, manipulasi atau pengubahan pada variabelmenyeluruh dan seksama segalah aktivitas yang berhubungan dengan penerapan kurikulum 2013. variabel yang diteliti, melainkan menggambarkan suatu kondisi yang apa adanya. Satu-satunya perlakuan yang diberikan hanyalah penelitian itu sendiri, yang dilakukan melalui observasi, wawancara, dan dokumentasi. Berdasarkan keterangan dari beberapa ahli di atas, dapat ditarik kesimpulan bahwa penelitian deskriptif kualitatif yaitu rangkaian kegiatan untuk memperoleh data yang bersifat apa adanya tanpa ada dalam kondisi tertentu yang hasilnya lebih menekankan makna. Tulisan ini menggunakan metode penelitian deskriptif kualitatif karena penelitian ini mengeksplor fenomena proses pembentukan karakter peserta didik melalui penyelenggaraan kantin kejujuran di SD Negeri 3 Purwodadi Kecamatan Tambak Kabupaten Banyumas. Selain itu penelitian ini juga bersifat induktif dan hasilnya lebih menekankan makna. 


\section{HASIL PENELITIAN DAN PEMBAHASAN}

\section{Hasil Penelitian}

Peneliti melakukan wawancara dengan Informan kunci yakni kepala sekolah SD Negeri 2 Hulaliu, guru kelas, ketua kelas dan orang tua untuk mendapatkan informasi mendalam tentang penguatan pendidikan karakter.

\section{a. Peran Kepala Sekolah dalam memberikan penguatan pendidikan karakter}

Berdasarkan hasil wawancara dengan kepala Sekolah Negeri 2 Hulaliu (November, 2020), sekolah ini menjadi wadah atau tempat untuk mendidik dan membentuk penyempurnaan diri (pendidikan karakter) para siswa serta melatih kemampuan diri secara terus menerus demi menuju ke arah hidup yang lebih baik. Peran orang tua untuk membantu pihak sekolah dalam memberikan penguatan pendidikan karakter bagi siswa tetap mendapat perhatian. Orang tua menjadi bagian dalam proses penguatan pendidikan karakter anak di sekolah karena pembinaan yang paling utama ada di dalam keluarga. orang tua haruslah menjadi contoh yang baik sehingga anak pun akan berusaha untuk meniru hal-hal yang dilakukan orang tua karena pada dasarnya perkembangan anak tidak dapat dilepaskan dari lingkungan tempat tinggalnya.

SD Negeri 2 Hulaliu bersama orang tua memiliki kepedulian yang tinggi terhadap perkembangan anak-anaknya. Hal ini sangatlah terlihat jelas dari aktifnya sebagian besar wali murid dalam kegiatan-kegiatan yang diselenggarakan wali murid untuk memberikan masukan dalam upaya meningkatkan mutu sekolah. SD Negeri 2 Hulaliu selalu melibatkan orang tua siswa sebagai salah satu upaya sekolah untuk menguatkan pembinaan karakter disekolah.

Selain itu SD Negeri 2 Hulaliu mengangkat nilai karakter sebagai bagian dari perumusan visi, misi dan tujuan lembaga serta berusaha keras mewujudkannya melalui kegiatan sehari-hari dan juga membangun hubungan yang baik antara guru dan siswa serta siswa dengan temannya. Strategi yang tidak kalah penting adalah tentang menyiapkan pendidik (guru) yang benar-benar berjiwa pendidik, bertanggungjawab terhadap kesuksesan pendidikan karakter peserta didiknya serta mengkondisikan lingkungan sekolah yang aman, nyaman dan baik dalam beribadah, bekerja dan bersosial.

Dalam pelaksaaan pendidikan karakter di sekolah ini, ada juga beberapa faktor yang menjadi hambatan terhadap suksesnya pelaksanaan pendidikan karakter. Beberapa di antaranya adalah peserta didik tidak bisa mengontrol dirinya, cepat bosan dan marah. Pada hakekatnya tidak semua siswa sama sehingga guru akan sedikit kewalahan. Jika kedapatan ada siswa yang melanggar peraturan dalam pembentukan karakter maka sudah menjadi tugas guru untuk mendidik, membimbing dan membina siswa kearah yang baik. Tanpa memberikan ancaman atau cara kekerasan yang berdampak buruk bagi siswa. Namun ada banyak faktor yang mendukung dimana siswa mampu berinteraksi dengan sesamanya, membentuk kelompok belajar, menjadi nyaman dengan lingkungan sekolahnya.

\section{b. Peran Guru Kelas dalam memberikan penguatan pendidikan karakter}

Berdasarkan hasil wawancara dengan guru kelas tinggi (Guru kelas IV, Kelas V, dan Kelas VI SD Negeri 2 Hulaliu), guru sebagai pendidik mempunyai tugas utama yaitu mendidik, mengajar, membimbing, mengarahkan, melatih dan menilai serta mengevaluasi siswa dalam mencapai tujuan pendidikan karakter. Guru sebagai motivator atau ujung tombak keberhasilan, sebagai seorang pendidik, guru juga sebagai patokan atau model bagi sikap anak didik. Untuk 
memiliki karakter yang baik, peran guru diperlukan. Guru bertugas untuk mengarahkan siswa ke arah yang lebih baik sehingga terbentuklah karakter siswa sesuai dengan bimbingan guru. Peran guru dalam memberikan penguatan pendidikan karakter pada masa pandemi Covid 19 sangat terbatas. Oleh karena itu guru sangat membutuhkan bantuan orang tua di rumah agar siswa dapat dikontrol dari rumah masing-masing. Orang tua harus bekerja sama dengan guru untuk menanamkan nilai-nilai karakter.

Menurut para guru (Wawancara, November 2020), beberapa penguatan pendidikan karakter yang sudah diterapkan di kelas antara lain yaitu sikap jujur, cinta kebersihan dan lingkungan, sikap peduli, cinta tanah air, religus kedisplinan, sopan santun, ramah, tekun, menghargai sesama dan guru, serta berjiwa kepemimpinan. Strategi yang dilakukan guru untuk memberika pengautan karakter bagi siswa ialah dengan menjadi role model atau contoh bagi siswa. Guru memperlakukan semua siswa sama tanpa memandang perbedaan sehingga dari sini siswa akan belajar mengikuti teladan yang diberikan guru. Strategi berikut yang dilakukan oleh guru dan orang tua adalah bekerja sama untuk mengatur akhlak dan mental anak didik agar bisa berperilaku baik.

Saat siswa melakukan melanggar peraturan yang telah ditetapkan, guru memberikan nasihat agar siswa tersebut tidak lagi mengulangi kesalahan yang sama terkait dengan peraturan dalam pembentukan karakter siswa. Siswa dibimbing supaya tetap menjadi siswa yang memiliki karakter yang baik. Dalam penilaian guru menilai indikator sikap spiritual dan sosial juga sikap, keterampilan. Selain itu juga ada penilaian penugasan, praktek, pengetahuan, kehadiran dari masing-masing siswa.

Menurut para guru, yang menjadi faktor penghambat bagi guru dalam meningkatkan penguatan pendidikan karakter siswa adalah tidak pernah terjadi proses belajaar secara langsung tatap muka dengan siswa karena pandemi Covid19 serta ada beberapa orang tua yang tidak memberikan perhatian kepada anaknya.

\section{c. Peran Siswa dalam memberikan penguatan pendidikan karakter}

Menurut hasil wawancara dengan ketua kelas, dalam mengajarkan pendidikan karakter, guru selalu memberi contoh tentang sikap yang baik, jujur, sopan dan santun. Siswa memahami bahwa pendidikan karakter terwujud dalam sikap yang sesuai dengan aturan sekolah yakni datang tepat waktu dan berpakaian rapih. Dalam sikap, ada teman yang bersikap baik dan ada juga teman yang bersikap tidak baik. Bersikap baik itu seperti diam dalam kelas ketika tidak ada guru dan tidak baik seperti, sering membuat keributan dalam kelas. Menurut penuturan ketua kelas sikap teman-teman di kelas tidak semuanya sama karenanya sebagai ketua kelas harus mengontrol teman-teman agar selalu bersikap baik. Dari pengamatannya, ada temannya yang suka belajar dan ada yang suka bermain di dalam kelas.

Menurut ketua kelas, siswa selalu dibantu oleh orang tua agar dapat berperilaku baik. Orang tua mendidik siswa untuk menghargai satu dengan yang lain dan mengajarkan anak untuk datang di sekolah tepat waktu serta menaati aturan di sekolah. Sementara tentang peran orang tua terhadap siswa, ketua kelas mengatakan bahwa orang tua akan menegurnya jika berbuat salah dan mendidiknya agar tidak lagi mengulagi kesalahan yang sama. 


\section{d. Peran Orang tua dalam memberikan penguatan pendidikan karakter}

Berdasarkan hasil wawancara dengan orang tua, mereka adalah figur atau contoh yang akan selalu ditiru oleh anak, untuk itu sebagai orang tua harus memberikan yang terbaik kepada anak-anaknya, memberi pengasuhan yang benar serta mencukupi kebutuhan dalam batas yang wajar dalam berkeluarga ketika orang tua menunjukan hal-hal yang baik maka, anak-anak yang berkarakter tidak mudah larut oleh budaya buruk dari luar juga akan menjadi anak yang berkepribadian baik.

Orang tua berkewajiban dan bertanggung jawab untuk mengasuh, memelihara dan melindungi tumbuh kembangnya anak sesuai dengan kemampuan, bakat dan minatnya dan memberikan pendidikan karakter dalam penanaman nilai budi pekerti pada anak.

Peran orang tua dalam membantu sekolah terkait dengan penguatan pendidkan karakter bagi anak adalah, keterlibatan orang tua dalam proses pendidikan dapat meningkatkan pencapaian prestasi belajar bagi anak-anak baik dalam kemampuan moral maupun intelektual yang paling mendasar adalah saling memberikan dorongan untuk anak. Orang tua menghimbau anak untuk setiap hari ke sekolah, mengecek setiap tugas yang diberikan oleh guru, wajib membayar uang sekolah turut bekerja sama dan mengambil bagian dalam kegiatan atau acara sekolah yang melibatkan siswa. Adanya kerja sama antara orang tua dan guru, agar anak tumbuh dengan karakter yang diharapkan orang tua dan guru harus memiliki visi dan misi yang sejalan, sekolah mendorong dan mendukung orang tua untuk melakukan pendidikan karakter dirumah dan sebaliknya orang tua mendukung sekolah untuk mengerjakan nilai-nilai dan karakter yang baik selama anak di sekolah.

Menurut orang tua, yang sering menjadi faktor penghambat pendidikan karakter ini adalah pola perilaku siswa terkadang sulit dimengerti, sarana prasarana tidak terjaga baik oleh siswa, kurangnya sarana penunjuang disekolah, kesibukan orang tua menyebabkan kurangnya perhatian dan kasih sayang kepada anak-anak. Sedangkan faktor pendukungnya adalah, proses pembelajaran yang berkualitas dan sarana prasarana yang memadai.

\section{PEMBAHASAN}

Dalam pembahasan ini akan dibahas lebih lanjut mengenai hasil penelitian dari strategi sekolah dalam penguatan pendidikan karakter bagi siswa dengan memaksimalkan peran orang tua, kendala yang dirasakan guru pada saat menerapkan strategi sekolah dan upaya yang dilakukan untuk mengatasi kendala dalam penerapan strategi sekolah dalam penguatan pendidikan karakter bagi siswa dengan memaksimalkan peran orang tua.

\section{Strategi Sekolah Dalam Penguatan Pendidikan Karakter}

Strategi sekolah dalam penguatan pendidikan karakter bagi siswa dengan memaksimalkan peran orang tua sangat membantu guru dalam proses belajar mengajar dikelas. Sekolah menjadi wadah atau tempat untuk mendidk dan membentuk karakter para siswa serta melatih kemampuan diri secara terus menerus demi menuju kearah hidup yang lebih baik. Guru sebagai pendidik yang mempunyai tugas utama yaitu mendidik, mengajar, membimbing, mengarahkan, melatih dan menilai serta mengevaluasi siswa dalam mencapai tujuan karakter. Guru sebagai motivator atau ujung tombak keberhasilan. Strategi yang dilakukan guru yaitu guru sebagai model 
untuk siswa atau sebagai patokan bagi sikap anak didik.

Selain itu orang tua juga harus bekerja sama dengan guru dalam memberikan penguatan pendidikan karakter bagi anak agar anak tumbuh dengan karakter yang diharapkan. Orang tua dan guru harus memiliki visi dan misi yang sejalan, yaitu sekolah mendorong dan mendukung orang tua untuk melakukan pendidikan karakter dirumah. Sebaliknya orang tua mendukung upaya sekolah untuk mengajarkan nilainilai dan karakter yang baik selama anak bersekolah. Oleh karena itu orang tua berperan penting dan turut menjadi bagian dalam proses penguatan pendidikan karakter anak disekolah, karena pembinaan yang paling utama ada didalam keluarga. Orang tua haruslah menjadi contoh yang baik sehingga anak pun akan berusaha untuk meniru hal-hal yang dilakukan orang tua, karena pada dasarnya anak tidak dapat dilepaskan dari lingkungan tempat tinggalnya. Hal-hal yang dilakukan orang tua dalam membantu sekolah terkait dengan penguatan pendidikan karakter bagi anak yaitu menghimbau anak untuk datang setiap hari kesekolah tepat waktu, mengecek setiap tugas yang diberikan guru dan meminta anak untuk mengerjakannya, menaati tata tertib yang ada disekolah, melakukan 18 nilai karakter yang diberikan oleh guru yaitu religius, jujur, toleransi, disiplin, kerja, keras, kreatif, mandiri, demokratis, rasa ingintahu, semangat kebangsaan, cinta tanah air, menghargai prestasi, bersahabat/komunikatif, cinta damai, gemar membaca, peduli lingkungan, peduli sosial dan tanggung jawab.

\section{Kendala Yang Dirasakan Guru Dalam Penerapan Strategi Sekolah Dalam Penguatan Pendidikan Karakter}

Berdasarkan temuan peneliti, kendala yang dirasakan guru dalam penerapan strategi sekolah dalam penguatan pendidikan karakter pada SD negeri 2 Hulaliu yaitu siswa tidak bisa mengontrol dirinya, cepat marah dan bosan karena hakekatnya tidak semua siswa sama. Selain itu kehadiran dari siswa tersebut juga menjadi penghalang, serta kurangnya komunikasi antara guru dan orang tua sehingga siswa tidak dapat dikontrol saat mengikuti proses belajar.

\section{Upaya Yang Dilakukan Untuk Mengatasi Kendala Dalam Penerapan Strategi Sekolah Dalam Penguatan Pendidikan Karakter}

Upaya yang dapat dilakukan untuk mengatasi kendala dalam penerapan strategi sekolah dalam penguatan pendidikan karakter adalah sebagai seorang pendidik, guru perlu menguasai strategi pembelajaran agar dapat menerapkan pendidikan karakter bagi sisiwa. Pendidikan karakter dalam hal ini berkaitan dengan 18 nilai karakter, oleh karena itu guru harus dapat menerapkannya dengan baik agar siswa dapat melakukan nilai-nilai tersebut. Dengan demikian maka kepribadian siswa akan terbentuk dengan baik. Selain itu, sekolah menyadari keterlibatan orang tua untuk membantu guru dalam penerapan pendidikan karakter sangat penting sehingga pihak sekolah sangat mengharapkan adanya kerja sama yang baik antara pihak sekolah dan orang tua. Misalnya guru dapat mengontrol anak saat belajar dirumah dan juga harus mematuhi aturan-aturan yang dibuat sekolah.

Kemudian pada saat siswa melanggar peraturan yang dibuat sekolah, maka orang tua dan guru dapat memberikan sanksi atau hukuman sebagai peneguran bagi siswa agar tidak melakukan pelanggaran, contohnya orang tua tidak mengizinkan anak bermain diluar rumah dan lain-lain. Pihak sekolah juga memberikan ruang untuk orang tua murid agar mereka dapat memberikan masukan dalam mencapai visi, misi dan tujuan sekolah serta dapat membangun hubungan yang baik antara guru dan siswa, 
dan siswa dengan temannya. Strategi yang tidak kalah penting adalah tentang menyiapkan pendidik yang benar-benar berjiwa pendidik, bertanggung jawab terhadap kesusksesan pendidikan karakter peserta didiknya, mengkondisikan lingkungan sekolah yang aman, nyaman dan baik dalam beribadah, bekerja dan bersosial.

\section{KESIMPULAN}

Berdasarkan hasil penelitian dan pembahasan pada strategi sekolah dalam penguatan pendidikan karakter, maka penelitian ini disimpulkan sebagai berikut:

1. Strategi sekolah adalahh pendekatan yang digunakan untuk mencapai tujuan sekolah, dengan menggunakan ide-ide dan gagasan untuk merencanakan dan menjalankan strategi yang dilaksanakan sekolah.

2. Pendidikan karakter adala usaha yang dilakukan secara sadar untuk menanamkan nilai-nilai atau sikap baik peserta didik sehingga dapat diwujudkan dalam lingkungan dan tingkah laku sehari-hari.

3. Dalam penerapan strategi sekolah dalam penguatan pendidikan karakter peneliti menemukan kendala yaitu pada SD negeri 2 Hulaliu siswa tidak bisa mengontrol dirinya, cepat marah dan bosan karena hakekatnya tidak semua siswa sama. Selain itu kehadiran dari siswa tersebut juga menjadi penghalang, serta kurangnya komunikasi antara guru dan orang tua sehingga siswa tidak dapat dikontrol saat mengikuti proses belajar.

4. Pihak sekolah memberikan ruang untuk orang tua murid agar mereka dapat memberikan masukan dalam mencapai visi, misi dan tujuan sekolah serta dapat membangun hubungan yang baik antara guru dan siswa, dan siswa dengan temannya. Strategi yang tidak kalah penting adalah tentang menyiapkan pendidik yang benar-benar berjiwa pendidik, bertanggung jawab terhadap kesusksesan pendidikan karakter peserta didiknya, mengkondisikan lingkungan sekolah yang aman, nyaman dan baik dalam beribadah, bekerja dan bersosial.

\section{DAFTAR PUSTAKA}

Arikunto Suharsmini. 2012. Prosedur Penelitian Suatu Pendekatan Praktek. Jakarta. Reneka Cipta.

Cipta

Dalimunthe. (2015.Strategi Dan Implementasi Pelaksanaan Pendidikan Karakter Di SMP

N 9 Yogyakarta. Jurnal Pendidikan Karakter, Tahun V, Nomor 1: 102-111.

Daryanto.2013. Implementasi Pendidikan Karakter di Sekolah. (Gava Media: Yogyakarta)

Darmiyati Zuchdi. (2011). Pendidikan Karakter dalam Prespektif Teori dan

Praktik. Yogyakarta: UNY Press

Darling N. (2007). Ecological Systems Theory: the Person in the Center of the Circles. Research in Human Development. 4 (3-4): 203-217

Dharma Kesuma, dkk. (2011) Pendidikan Karakter: Kajian Teori dan Praktik di Sekolah. Bandung: PT Remaja Rosdakarya

Doni Kesuma A. (2009). Pendidikan Karakter di Zaman Keblinger. Jakarta: Grasindo.

Johannes, N. Y., Ritiauw, S. P., \& Abidin, H. (2020). Implementasi Budaya Sekolah dalam

Mewujudkan Pendidikan Karakter di SD Negeri 19 Ambon. PEDAGOGIKA: Jurnal

Pedagogika dan Dinamika Pendidikan, 8(1), 11-23.

Kementerian Pendidikan Nasional. 2010. Pengembangan Pendidikan Budaya dan 
Karakter Bangsa: Pedoman Sekolah. Jakarta: Badan Penelitian dan Pengembangan Pusat Kurikulum.

Kesuma, dkk. 2011. Pendidikan Karakter: Kajian Teoridan Praktik di Sekolah, Bandung:

PT. Remaja Rosdakarya.

Lexy J. Moleong. (2013). Metode Penelitian Kualitatif. Bandung : PT Remaja Rosdakarya

Lickona. 1991. Educating for Character, How Our Schools Can Teach Respect and

Responsibility. New York: Bantam Books.

Masnur Muslich. (2011). Pendidikan Karakter: Menjawab Tantangan Krisis Multi dimensional. Jakarta: Bumi Aksara.

Miller PH. (2011). Theories of Developmental Psychology: Fifth Edition. New York: Worth Publishers.

Muchlas Samani. (2012). Konsep dan Model Pendidikan Karakter. Bandung: PT Remaja Rosda Karya

Novika Malinda Safitri (2015). Implementasi Pendidikan Karakter Melalui Kultur Sekolah Di Smp N 14 Yogyakarta. Jurnal Pendidikan Karakter, Tahun V, Nomor2 : 173-183

Peraturan Presiden Republik Indonesia No. 87 Tahun 2017 tentang Penguatan Pendidikan Karakter. Jakarta: Depdiknas.

Ryan dan Lickona, (1992). Character Development: The Challange and the Model". Di dalam: Character Development in School and Beyond. Cultural Heritage and Contemporary Change, Series IV. Foundation of Moral Education, Volume 3

Safitri, N. M. (2015). Implementasi pendidikan karakter melalui kultur sekolah di SMP N 14 yogyakarta. Jurnal Pendidikan Karakter, (2).

Samani dan Hariyanto.2011. Konsepdan Model Pendidikan Karakter. Bandung: Remaja Rosdakarya

Sandarwati, Inira, F. (2016). Pengaruh Lingkungan Sosial Siswa Dan Kondisi Ekonomi Orang Tua Terhadap Prestasi Belajar Siswa di SMP Negeri 9 Kota Probolinggo. Jurnal Penelitian dan Pendidikan IPS (JPPI) Volume 10 No 2: 245-260.

Saiful Bahri.2015. Implementasi Pendidikan Karakter dalam Mengatasi Krisis Moral di Sekolah. TA'ALLUM Vol 03.

Siskandar (2003:22). Peran Orang Tua Dalam Pendidikan Karakter. Jakarta: Prenada Media Group.

Soesilo, Nining. (2002). Manajemen Strategi disektor Publik. Jakarta: Fakultas Ekonomi Universitas Indonesia

Sugiyono. (2009). Metode Penelitian Pendidikan Pendekatan Kuantitatif, Kualitatif dan R \& D. Bandung: Alfabeta

Sugiyono. (2012). Metode Penelitian Pendidikan Pendekatan Kuantitatif, Kualitatif, dan R\&D. Bandung: Alfabeta

UNICEF. (2014). Hidden in Plain Sight: A Statistical Analysis of Violence Against Children. New York: UNICEF.

Walker L J. (1999). "The Family Context for Moral Development". Journal of Moral Education. 28.

Wulandari, Y., \& Kristiawan, M. (2017). Strategi sekolah dalam penguatan pendidikan karakter bagi siswa dengan memaksimalkan peran orang tua. JMKSP (Jurnal Manajemen, Kepemimpinan, dan Supervisi Pendidikan), 2(2), 290-302.

Zubaedi.(2011). Desain Pendidikan Karakter Konsepsi dan Aplikasinya dalam Lembaga Pendidikan. Jakarta: Prenada Media Group. 